\title{
THE STATUS OF A POST-DATED CHEQUE PRIOR TO THE POST-DATE*
}

\author{
Phillemon Makakaba \\ UDE LLB LLM \\ Faculty of Law \\ University of South Africa (UNISA)
}

\section{SUMMARY}

Electronic payment seems to be taking over but cheques are still used for valid reasons. Post-dated cheques are used for reasons such as making an advance payment, securing future payment at a future time, etcetera. However, the status of post-dated cheques prior to the post-date has been questionable since many years ago. The consumers who were affected by this situation were for decades placed in a quandary since the courts had been unable to resolve the uncertainty.

This article is an analysis of the status of post-dated cheques prior to the post-date according to the South African law of negotiable instruments. A comparative study of English law is undertaken since the South African law of negotiable instruments is derived from the English law; hence the English law position is imperative and influential in regard to the South African law of negotiable instruments. Consideration is given to the South African and English legislation for the definitions of concepts such as a bill of exchange, cheque, payable on demand, etcetera. It will be shown that post-dated cheques are regarded as demand instruments and thus valid cheques in both South African law and English law.

\section{INTRODUCTION}

Electronic payment seems to be taking over traditional methods of payment. However, many people are still using post-dated cheques for various reasons. A post-dated cheque is an instrument of payment which is expressed to be payable on a date some time in the future but its status prior to the post-date had been unclear since many years ago, that is whether or not functions as a cheque prior to the post-date. The question of whether a post-dated cheque is a cheque prior to the post-date stems from the consequence of the date that appears on it, which is the date on which the payment should be made, is in the future; hence the question of whether a post-dated cheque is payable on demand or not. What remains clear is that it is a bill drawn on a bank. ${ }^{2}$ The status of a post-dated cheque prior to the post-date had been unclear in many countries ${ }^{3}$ and that resulted in much

* This article is based on an unpublished dissertation that was submitted for LLM at University of South Africa.

See some of the reasons in par 3 below.

2 See the submissions made by the author in par 4 below.

3 Verdun "Postdated Checks: An Old Problem with a New Solution in the Revised U.C.C." 199114 University of Arkansas at Little Rock LJ 37 39-40. 
academic discourse. ${ }^{4}$ The consumers who were affected by this situation were for decades placed in a quandary since the courts had been unable to resolve this uncertainty. ${ }^{5}$ The aim of this article is to determine whether a post-dated cheque is a cheque prior to the post-date: that is, whether it is payable on demand, according to the South African law of negotiable instruments. A comparative study of English law will be undertaken since the South African law of negotiable instruments is derived from the English law; hence the English law position is imperative and influential to the South African law of negotiable instruments.

\section{HISTORICAL BACKGROUND OF CHEQUES}

Throughout the world, barter was used as a practice to obtain goods for many centuries. Resulting from the process of civilization, people started to use notes and coins, then paper payment and, lastly, electronic payment as the means of remittance. ${ }^{6}$ The cheque is of European origin ${ }^{7}$ and reached its full development in England. ${ }^{8}$

Prior to the establishment of the Union of South Africa in 1910, the South African law of negotiable instruments was codified separately by the four colonies. ${ }^{9}$ Each colony promulgated its own statute separate from statutes in other provinces. ${ }^{10}$ These statutes were amended several times over the years and finally repealed and replaced by the Bills of Exchange Act 34 of 1964. ${ }^{11}$ Since its promulgation, the SABEA has been amended several times. $^{12}$ The most important amendments were made by the Bills of Exchange Amendment Act 56 of $2000 .^{13}$

\section{PAYMENT BY MEANS OF CHEQUES}

Under normal circumstances, when a person undertakes to make payment by cheque, a legal obligation of payment is imposed and monetary obligations must be discharged by means of legal tender, that is to say, by

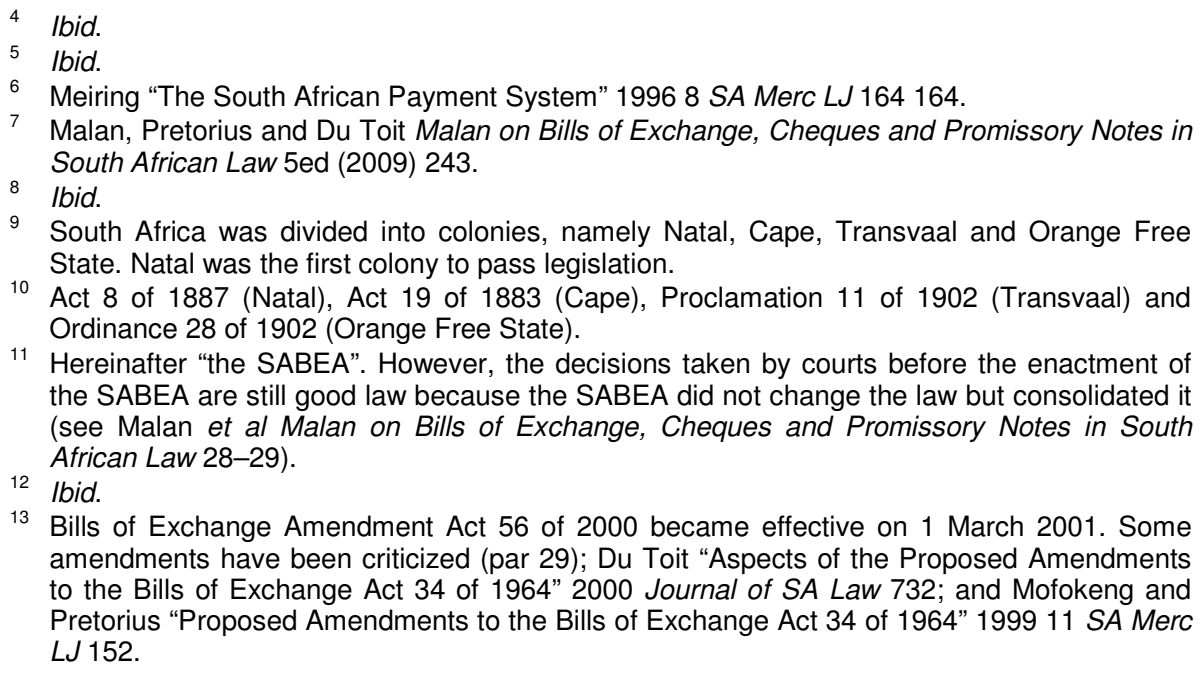

9 South Africa was divided into colonies, namely Natal, Cape, Transvaal and Orange Free State. Natal was the first colony to pass legislation.

10 Act 8 of 1887 (Natal), Act 19 of 1883 (Cape), Proclamation 11 of 1902 (Transvaal) and Ordinance 28 of 1902 (Orange Free State).

11 Hereinafter "the SABEA". However, the decisions taken by courts before the enactment of the SABEA are still good law because the SABEA did not change the law but consolidated it (see Malan et al Malan on Bills of Exchange, Cheques and Promissory Notes in South African Law 28-29).

13 Bills of Exchange Amendment Act 56 of 2000 became effective on 1 March 2001. Some amendments have been criticized (par 29); Du Toit "Aspects of the Proposed Amendments to the Bills of Exchange Act 34 of 1964" 2000 Journal of SA Law 732; and Mofokeng and Pretorius "Proposed Amendments to the Bills of Exchange Act 34 of 1964" 199911 SA Merc LJ 152.

$12 \mathrm{Ibid}$. 
the payment of "money". ${ }^{14}$ Despite the fact that a valid cheque represents money, it is trite law that a cheque is neither money ${ }^{15}$ nor legal tender. ${ }^{16}$ The "creditor to whom a money debt is owing, may insist on strict compliance with the contract and demand payment by means of legal tender, that is, cash" ${ }^{17}$ Payment made by a cheque depends on the agreement made between a debtor and a creditor. It is the principle of our law that the debtor is entitled to use a cheque for payment, only when the creditor expressly or by implication agrees to accept such payment as payment of a debt. ${ }^{18}$

The cheque will then be used for the payment of a debt as per agreement between the creditor and the debtor which is by way of delivery. ${ }^{19}$ The court in B\&H Engineering $v$ First National Bank of SA $L t d^{20}$ held that the delivery of a cheque did not extinguish the original obligation or underlying obligation and there would be a suspension of the action arising from the underlying obligation, and this would remain until the cheque was honoured. ${ }^{21}$ In Eriksen Motors (Welkom) Ltd $v$ Protea Motors, Warrenton, ${ }^{22}$ the court held that payment by cheque was prima facie regarded as immediate payment subject to a condition. The condition is that if the cheque is honoured on presentation and that will mean that the date of giving of a cheque is the date of payment. There is no payment when a cheque is dishonoured. The debtor (drawer) is entitled, in terms of common law, to countermand payment of a cheque if he pays a debt or meets the obligation by means of cheque. ${ }^{23}$ The duty and authority of a bank to pay a cheque is terminated by countermanding payment and presentment for payment is dispensed with. ${ }^{24}$

Post-dated cheques still serve as a useful device and convenient instrument of credit to the mercantile community. When a person draws a post-dated cheque, he prevents the bank from paying a cheque and debiting the drawer's account prior to the post-date. ${ }^{25}$ Post-dated cheques can be used for many reasons such as the following:

(a) To make an advance payment.

14 The concept "money" is not defined in South African law. However, s 14, s 15 and s 17 of the South African Reserve Bank Act 90 of 1989 provide information regarding bank notes and coins.

15 A cheque is not even currency (see Vergari Checks, Payments and Electronic Banking (1986) 9)

16 Malan et al Malan on Bills of Exchange, Cheques and Promissory Notes in South African Law 268.

17 Nagel and Pretorius "Countermanding Payment of a Cheque" 200467 THRHR 640640 641 .

$18 \mathrm{Ibid}$. In some cases the creditor, in the absence of an agreement may be estopped from insisting on the payment in cash (see Nagel and Pretorius "Countermanding Payment of a Cheque" 2004 Journal of Contemporary Roman-Dutch Law 641). See also Malan et al Malan on Bills of Exchange, Cheques and Promissory Notes in South African Law 269. This was also held in Estate Lowry v Saporiti (1909) 30 NLR 3543.

19 Makakaba "Rubber Cheques" 200715 Juta's Business Law 1718.

201995 (2) SA 279 (A).

${ }^{21}$ B\&H Engineering $v$ First National Bank of SA Ltd supra par 285-286.

221973 (3) SA 685 (A) 693.

23 Nagel and Pretorius 200467 THRHR 643.

24 Ibid.

25 Gering assisted by Tobias Handbook on the Law of Negotiable Instruments 3 ed (2007) 171. 
(b) To secure future payment at a future time.

(c) To delay payment for example, where a particular piece of work to be paid for is not yet completed.

(d) To record the date of payment and the amount of the drawer's indebtedness.

(e) Some people use post-dated cheques because they do not have enough money in their accounts at the time they are drawn.

For an instrument of payment to be regarded as a valid cheque in terms of South African law of negotiable instruments, it must meet the criteria of a "cheque" as set by the definition of a "cheque" in the SABEA.

\section{THE DEFINITION OF A "CHEQUE"}

Section 1 of the SABEA defines a "cheque" as "a bill drawn on a bank payable on demand" ${ }^{26} \mathrm{~A}$ bill of exchange is defined in section 2 of the SABEA as:

"an unconditional order in writing, addressed by one person to another, signed by the person giving it, requiring the person to whom it is addressed to pay on demand, or at a fixed or determinable future time, a sum certain in money to a specified person or his order, or to bearer".

A combined and comprehensive definition of a cheque is thus an unconditional order in writing, addressed by one person to a bank, signed by the person giving it, requiring the bank to whom it is addressed to pay on demand, a sum certain in money to a specified person or his order or to bearer.

The author submits that a post-dated cheque clearly meets the requirements of a "bill" as provided in section 2 of the SABEA. ${ }^{27}$ As for section 1 of the SABEA, the author submits further that a post-dated cheque is "drawn on a bank", which is one of the requirements of a cheque; hence a bill drawn on a bank. ${ }^{28}$ If a post-dated cheque clearly met the last requirement of "payable on demand", it would clearly meet the criteria of a cheque in terms of the SABEA and thus be a valid cheque in terms of South African law of negotiable instruments.

\section{THE DEFINITION OF "PAYABLE ON DEMAND"}

The concept, "demand" means that, if a cheque is presented on the date it bears or within reasonable time, ${ }^{29}$ payment will be made. It does not necessarily mean that a cheque must be cashed immediately. ${ }^{30}$ According to Tobias the words "payable on demand" or "pay on demand" do not mean

\footnotetext{
${ }^{26} \mathrm{~S} 1$ of the SABEA.

${ }^{27}$ It is thus not necessary to give all the requirements provided by $\mathrm{s} 2$ in detail.

28 See par 1 above.

$29 \mathrm{~S} 72(2)$ of the SABEA provides that in determining what is a "reasonable time" regard shall be had to the nature of the instrument, the usage of trade and of banks and the facts of the particular case.

30 Oelofse "Die Aard van 'n Vooruitgedateerde Tjek" 19813 Modern Business Law 5153.
} 
that a cheque can be cashed immediately. ${ }^{31}$ The Oxford Dictionary of $E_{\text {English }}^{32}$ defines "demand" as "an insistent and peremptory request, made as of right". ${ }^{33}$

Section $8(1)$ of the SABEA provides that a bill is payable on demand under the following:

(a) if it is expressed to be payable on demand, at sight, or on presentation; or

(b) if no time for payment is expressed therein.

In the context of the law of negotiable instruments, the expression "payable on demand" should mean that an instrument must be paid when demand is made by the holder. The demand is made by the holder on the date which the instrument bears or within a reasonable time. ${ }^{34}$

There have been a lot of arguments by academic writers on whether a post-dated cheque is payable on demand or not. According to Cowen a bill is payable on demand if no time for payment is expressed therein, in a case of a post-dated cheque, a fixed due date for payment is expressed. ${ }^{35}$ There are some authors who opine that a post-dated cheque is a bill payable on the future date. ${ }^{36}$ There is also an argument that, although a post-dated cheque is not a cheque prior to the post-date, it becomes a cheque on the arrival of the post-date. ${ }^{37}$ Tobias maintains that, from its inception, a postdated cheque is a demand instrument and the deferring of "demand" until the post-date or a reasonable time thereafter when payment will be made does not transform this kind of instrument into anything other than what it was at its inception. ${ }^{38} \mathrm{Nagel}$ and Pretorius mention that a post-dated cheque

31 Tobias "Conversion of a Post-Dated Bearer Instrument into an Order Instrument by Special Endorsement and the Fate of a Prospective Holder in Due Course" 200924 Banking \& Finance $L R 343347$

32 Soanes and Stevenson Oxford Dictionary of English 2ed (revised) 2005.

33 Soanes and Stevenson Oxford Dictionary of English 461.

$34 \mathrm{~S} 43$ of the SABEA provides -

"(1)(a) Subject to the provisions of this Act, a bill must be duly presented for payment in accordance with the provisions of subsection (2).

(b) If it is not so presented, the drawer and indorsers shall be discharged.

(2) A bill is duly presented for payment if it is presented in accordance with the following rules, namely-

(a) if the bill is not payable on demand, presentment must be made on the day it falls due;

(b) if the bill is payable on demand, presentment must, subject to the provisions of this Act, be made within a reasonable time, within the meaning of subsection (3), after its issue, in order to render the drawer liable, and within such a reasonable time after its endorsement, in order to render the indorser liable."

35 Cowen assisted by Gering The Law of Negotiable Instruments in South Africa 5ed (1985) 190.

36 Hedley Bills of Exchange and Bankers' Documentary Credits 4ed (2001) 199; and Verdun 199114 University of Arkansas at Little Rock LJ 39.

37 Malan et al Malan on Bills of Exchange, Cheques and Promissory Notes in South African Law 250.

38 Tobias 2009 Banking \& Finance LR 347. 
can be negotiated before the post-date. ${ }^{39}$ Gering sees a post-dated cheque as a valid cheque on or after the post-date since it is treated as a cheque on or after the post-date. ${ }^{40}$ Holmes JA in Standard Bank of SA Ltd $v$ Sham Magazine Centre, ${ }^{41}$ held that "it was not disputed that this post-dated cheque became valid as a cheque on or after the period of the post-date". ${ }^{42}$

\section{THE COURT'S APPROACH TO THE STATUS OF A POST-DATED CHEQUE}

In Sham Magazine Centre, the court had the opportunity to decide on the status of a post-date cheque. ${ }^{43}$ In this case, Sham Magazine Centre drew a post-dated cheque "to the order of Transvaal Watch (Pty) Ltd". Transvaal Watch (Pty) Ltd endorsed the post-dated cheque in favour of Standard Bank and delivered it. The cheque was dishonoured for want of funds on presentation for payment on the post-date. The court had to decide whether Standard Bank was the holder of the post-dated cheque. In order to decide on this matter, the court dealt among others ${ }^{44}$ with a question of the validity of a post-dated cheque and held that a post-dated cheque became a valid cheque on or after the post-date. ${ }^{45}$

The latest South African judgment on the status of a post-dated cheque is African Bank Ltd v Covmark Marketing CC; African Bank Ltd v Soodhoo. ${ }^{46}$ The facts of this case were that Covmark Marketing CC (Covmark) drew three post-dated cheques payable to "Wilmington" (admitted to be Wilmington Personal Care CC or Wilmington Personal CC). The printed words "or Bearer/of Toonder" were not deleted. These three cheques at the amounts of R750, 000.00, R1, 500,000.00 and R875, 000.00 were dated 30 April 2004, 31 May 2004 and 31 May 2004 respectively. Payment on each cheque was stopped. Wilmington endorsed these cheques specially viz "to the order of African Bank Ltd t/a AB Commerce" and were delivered to African Bank before the date on the cheques arrived. ${ }^{47}$

One of the pertinent questions before the court ${ }^{48}$ was to decide whether or not a person who acquires a post-dated cheque prior to the post-date could qualify as the holder in due course in terms of section 27 of the SABEA. ${ }^{49}$ The court was thus compelled to decide firstly on the status of a post-dated cheque before the post-date. African Bank argued that it indeed qualified as

\footnotetext{
39 Nagel and Pretorius "Post-Dated Cheques 'Irregular' Indorsements and Holdership in Due Course" 200973 Journal of Contemporary Roman-Dutch Law 677683.

40 Gering 1977 South African LJ 161.

411977 (1) SA 484 (A).

42 Standard Bank of SA Ltd $v$ Sham Magazine Centre supra par 505E.

43 The court had to decide whether a post-dated cheque was valid as a cheque before the post-date.

44 The court dealt with other issues that are not relevant to this article.

45 Standard Bank of SA Ltd v Sham Magazine Centre supra par 505E.

462008 (6) SA 46 (D).

47 It was a common cause between the parties that all three cheques were, at the time of delivery to the African Bank post-dated and the post-date had not arrived.

48 Durban and Local Division, as it was then known, now the KwaZulu-Natal High Court, Durban.

49 Another legal question concerned the endorsement and is thus not relevant to this article.
} 
the holder in due course; whilst the defence was that the cheques in question were post-dated and were not valid cheques at the time they were delivered to African Bank.

The argument advanced was that a post-dated cheque was not a cheque in terms of section 1 of the SABEA on the basis that it was not payable on demand, which is the criterion of the definition of a cheque in section 1 of the SABEA.

The judge rejected the contention that a post-dated cheque was not a cheque since it was not payable on demand. ${ }^{50}$ Moosa AJ also dealt with the argument that, although a post-dated cheque is not a cheque when issued, it becomes a cheque on the post-date. Having referred to the definitions of different instruments in the SABEA, Moosa AJ held that a cheque is a type of a bill and as provided by the definition in section 2(1), it is a demand instrument which is addressed to a bank. ${ }^{51}$

The court also held that section 11(2) of the SABEA is there to remove the doubts as to the status of a post-dated cheque. ${ }^{52}$ Moosa AJ stated that in the absence of section 11(2) of the SABEA, ${ }^{53}$ the status of a post-dated cheque would still be unclear. The court held further that when reading section 11(2) of the SABEA together with the definition of a bill of exchange in section 2(1) of the SABEA and the definition of a cheque in section 1 of the SABEA, it had the effect of rendering such an instrument a demand instrument notwithstanding that the effective date of demand might be sometime in the future. ${ }^{54}$ And in that context, the word "demand" had to be contrasted with a "fixed" or "determinable future time". ${ }^{55}$ The judge also mentioned that in practice a post-dated cheque was treated as payable on demand on or after the post-date. ${ }^{56}$

The judge finally concluded that in all the circumstances he found that there was no merit in the contention that post-dated cheques were not cheques as countenanced by the SABEA. He held that a post-dated cheque was a bill as countenanced under SABEA ${ }^{57}$ and although a cheque was by definition payable "on demand", a post-dated cheque was nonetheless a valid cheque even before the post-date arrived and it was possible for

50 Nagel and Pretorius 2009 Journal of Contemporary Roman-Dutch Law 678.

51 Ibid. See also African Bank Ltd v Covmark Marketing CC; African Bank Ltd v Soodhoo supra par 57B.

52 African Bank Ltd v Covmark Marketing CC; African Bank Ltd v Soodhoo supra par 57B.

${ }^{53} S$ 11(2) of the SABEA provides: "A bill is not invalid by reason only that it is antedated or post-dated, or that it bears the date of a non-business day".

54 African Bank Ltd v Covmark Marketing CC; African Bank Ltd v Soodhoo supra par 56G-H. See also Malan et al Malan on Bills of Exchange, Cheques and Promissory Notes in South African Law 250. Tobias also submitted this view in respect of the status of a post-dated cheque (see Tobias "The Myth of the Post-Dated Cheque Revisited and the Holder in Due Course" 200719 SA Merc LJ 186 188).

55 African Bank Ltd v Covmark Marketing CC; African Bank Ltd v Soodhoo supra par 58B-D; and Hodgson \& Lee Pty Ltd $v$ Mardonius Pty Ltd (1986) 5 NSWLR 496 (CA) 498B-D.

56 African Bank Ltd v Covmark Marketing CC; African Bank Ltd v Soodhoo supra par 571-58B. See also Nagel and Pretorius 2009 Journal of Contemporary Roman-Dutch Law 678.

57 The court held further that a party such as the African Bank might indeed become the holder in due course of such an instrument, even if the instrument was negotiated before the date which the instrument bore arrived. 
African Bank to become the holder in due course of such an instrument, even if it was negotiated prior to the arrival of the date which the instrument bore. $^{58}$

\section{COMPARATIVE STUDY: ENGLISH LAW}

The English law seems to also have had some confusion on the status of a post-dated cheque. ${ }^{59}$ According to Guest a post-dated cheque is clearly a cheque once the date written on it arrives but its status is unclear prior to the post-date. ${ }^{60}$ The confusion on the status of a post-dated cheque continued even after the promulgation of the Bills of Exchange Act of 1882. ${ }^{61}$ The BEA served as a model in many Commonwealth countries. ${ }^{62}$ As a result of this, there is a great similarity in the Southern African countries' bills of exchange legislation including South Africa's ${ }^{63}$ to the extent that there are many corresponding provisions between the SABEA and the BEA. ${ }^{64}$ The BEA as well as its multiple Commonwealth progeny, is recognized as "the best drafted Act of Parliament that was ever passed". 65

\section{THE ENGLISH LAW DEFINITION OF A "CHEQUE" AND "PAYABLE ON DEMAND"}

Section 73 of the BEA defines a cheque as "a bill of exchange drawn on a banker, payable on demand". In addition to the definition of a cheque, to qualify as a cheque, an instrument must also satisfy definition of a bill of exchange as provided by section $3(1)$ of the BEA. ${ }^{66}$ The provisions of the

58 African Bank Ltd v Covmark Marketing CC; African Bank Ltd v Soodhoo supra par 59B-C. There are also two aspects which are important to mention although they fall outside the scope of this article. Firstly, African Bank ultimately failed to qualify as the holder in due course because of the special endorsement on a cheque (see par 59B-C) and secondly, the court held that the purported conversion of the bearer cheques into an order instrument by special endorsement, meets the test of a material irregularity because it alters the liability of the parties to a bill, and this excludes the subsequent holder from becoming the holder in due course (see par 63C-D). The second aspect was subject to criticism. Pretorius pointed out that the concession that there was an attempt to convert the bearer cheques to order cheques was indeed ill-conceived (see Pretorius "Post-Dated Cheques and the Holder in Due Course" 2010 Annual Banking Law Update 1 6). However, Pretorius congratulated Moosa AJ on the judgment and mentioned that the court was perhaps pointed in the wrong direction by the concession (7). See also Nagel and Pretorius 2009 Journal of Contemporary Roman-Dutch Law 683.

59 Palfreman The Law of Banking (1980) 239.

60 Guest Chalmers and Guest on Bills of Exchange, Cheques and Promissory Notes on Bills of Exchange, Cheques and Promissory Notes 17ed (2009) 81.

61 Hereinafter "the BEA".

62 Including South Africa (see Malan et al Malan on Bills of Exchange, Cheques and Promissory Notes in South African Law 29).

63 Malan, Oelofse and Pretorius Proposals for the Reform of the Bills of Exchange Act, 1964 (Working paper 22 South African Law Commission (1989)) 29.

64 This does not automatically mean that the legal consequences will be the same (see Malan et al Malan on Bills of Exchange, Cheques and Promissory Notes in South African Law 28).

65 Malan et al Malan on Bills of Exchange, Cheques and Promissory Notes in South African Law 20.

${ }^{66} S 3(1)$ of the BEA defines a bill of exchange exactly the same as s 2 of the SABEA (see par 4 above for what s 2 provides). 
BEA applicable to bills payable on demand apply equally to cheques unless otherwise provided.

Section 10(1) of the BEA provides that an instrument will not be a bill payable on demand by virtue of paragraph (b) of this section, in which no time for payment is expressed if a time for payment is expressed but that time is not a fixed or determinable future time within section 3(1) and section 11 of the BEA, nor will it be such a bill, if wording intended to express a time for payment, is defective or unintelligible. ${ }^{67}$

According to McLoughlin, a cheque drawn post-dated is payable on presentment ${ }^{68}$ for payment and not presentation for acceptance. The presentment for payment will be made on the date which the instrument bears or within reasonable time thereafter. ${ }^{69}$ McLoughlin mentions that the words "payable on demand" in the definition, do not necessarily mean that a cheque can be cashed immediately but, that if a cheque is presented on the date it bears or within a reasonable time from the date it bears, payment will be made. ${ }^{70}$

\section{THE RELEVANT ENGLISH CASE LAW}

The court in Royal Bank of Scotland $v$ Tottenham ${ }^{71}$ was faced with a question concerning the validity of a post-dated cheque. In this case Tottenham drew a cheque to the order of Cecil Hambrough, dated 10 August 1893. The cheque was delivered to Hambrough on 3 August. The cheque was endorsed and delivered to Mrs Manson who finally sent a cheque to the Royal Bank on 7 August. The Royal Bank received the cheque and placed it to Mrs Manson's credit according to her instruction. On 10 August Tottenham gave notice to his bank to stop the cheque. On 11 August the Royal Bank received a notice from their London office reporting nonpayment of the cheque on presentment. The Royal Bank's manager debited Mrs Manson's account with the amount on the cheque, thus making her a debtor to the bank for the amount which had been paid by the Royal Bank, on the faith of a cheque being met and before notice of dishonour. The cheque was presented again, but dishonoured.

The issue before the court was whether Royal Bank was the holder in due course of a post-dated cheque. The court had to deal with the status of a post-dated cheque before it could decide whether Royal Bank was the holder in due course. The court held that a post-dated cheque was valid and negotiable prior to the post-date. ${ }^{72}$

\footnotetext{
McLoughlin Introduction to Negotiable Instruments (1975) 128-129.

Ibid.

Ibid.

Ibid.

[1894] 2 QB 715 (CA).

72 The court held further that a post-dated cheque was not incomplete or irregular on the face of it, but post-dated, and a person who took a post-dated order or bearer cheque in good faith and for value might become the holder in due course (these aspects are outside the scope of this article). The decision is the same as the decision made by Moosa AJ in African Bank Ltd v Covmark Marketing CC; African Bank Ltd v Soodhoo (the decision can be found in par 5 above). Samuels JA also concluded that since no time for payment was expressed
} 
The judgment shows that English law recognizes a post-dated cheque as a cheque in terms of the BEA. Guest ${ }^{73}$ mentioned that there was no doubt that firstly in view of section $13(2)^{74}$ of the BEA, a post-dated cheque was not invalid. ${ }^{75}$ Secondly, if a post-dated cheque is drawn payable to order or to the bearer it can be negotiated between the date of its issue and the date written upon it. ${ }^{76}$ The mere fact that it is post-dated does not mean that it is delivered subject to a condition suspending the operation of the instrument until the arrival of a post-date. ${ }^{77}$ Thirdly, a person who takes a post-dated order cheque or a post-dated bearer cheque in good faith and for value may become the holder in due course. ${ }^{78}$

When the client of a bank draws a post-dated cheque, he gives the bank a mandate not to make payment until the post-date arrives. If the bank pays a post-dated cheque prematurely, it cannot debit the drawer's account until the post-date arrives because it has no mandate to pay until the post-date. ${ }^{79}$ Guest explains that it is only when the post-date arrives, without the drawer's countermand or revocation, that the bank may then debit its customer's account lawfully. ${ }^{80}$ According to McLoughlin a cheque is payable on demand even if it is post-dated, however, if it is post-dated, the demand cannot be made lawfully until the date indicated. ${ }^{8}$

\section{CONCLUSION}

A post-dated cheque is a cheque that complies with the definition of a cheque in terms of section 1 of the SABEA. Section 11(2) removes the doubts as to the status of a post-dated cheque.

All cheques are by definition bills of exchange ${ }^{82}$ and the argument that a post-dated cheque is a bill payable on the future date, does not contradict the fact that a post-dated cheque is a cheque prior to the post-date. In terms of section 1 of the SABEA for the instrument to be a cheque, it must be a bill. ${ }^{83}$ An instrument which does not meet the requirements of a bill of exchange as provided in section 2 of the SABEA will simply not qualify as a

on post-dated cheques, they were payable on demand and after the date they bore (see Hodgson \& Lee Pty Ltd v Mardonius Pty Ltd (1986) 498D).

73 Guest Chalmers and Guest on Bills of Exchange, Cheques and Promissory Notes on Bills of Exchange, Cheques and Promissory Notes 81-82.

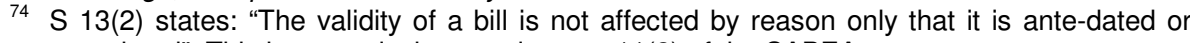
post-dated". This is an equivalent section to s 11(2) of the SABEA.

75 As held in Royal Bank of Scotland $v$ Tottenham supra [1894] 719.

76 This application is exactly the same as any other cheque (see Guest Chalmers and Guest on Bills of Exchange, Cheques and Promissory Notes on Bills of Exchange, Cheques and Promissory Notes 82).

77 Ibid.

78 Ibid.

79 Guest Chalmers and Guest on Bills of Exchange, Cheques and Promissory Notes on Bills of Exchange, Cheques and Promissory Notes 628.

80 Ibid.

81 McLoughlin Introduction to Negotiable Instruments 129.

82 In contrary all bills of exchange are not cheques (see Guest Chalmers and Guest on Bills of Exchange, Cheques and Promissory Notes on Bills of Exchange, Cheques and Promissory Notes 626).

83 See par 4 above. 
cheque in terms of section 1 of the SABEA. A post-dated cheque clearly meets all the criteria of a bill as stated in section 2 of the SABEA. ${ }^{84}$ A postdated cheque is undoubtedly drawn on the bank in accordance with section 1 of the SABEA ${ }^{85}$ and the criterion of "payable on demand" comes into picture.

The remaining criterion of "payable on demand" was correctly addressed in African Bank in which the Moosa AJ held that concept "payable on demand" was incorrectly associated with "immediate payment". The judge held correctly that a post-dated cheque is a demand instrument notwithstanding that the effective date of demand may be some time in the future. ${ }^{86}$ The concept "payable on demand" is found not to mean "payable immediately", ${ }^{87}$ and in a case of a post-dated cheque, the court held that the demand is accordingly suspended until the post-date arrives.

It is correct that section $11(2)$ of the SABEA, ${ }^{88}$ read together with the definition of a bill of exchange in section 2(1) of the SABEA and the definition of a cheque in section 1 of the SABEA, has the effect of rendering a post-dated cheque a demand instrument, notwithstanding that the effective date of demand may be some time in the future. ${ }^{89}$ By interpreting section 11(2), Moosa AJ clarified the confusion of the concept "payable on demand" which was incorrectly associated with "immediate payment".

The plea made by Tobias $^{90}$ that in South Africa, a post-dated cheque should be recognized as a valid cheque prior to the post-date was confirmed by authority ${ }^{91}$ and it is also the position in English law. ${ }^{92}$ This is not surprising since when interpreting the SABEA, the South African courts are influenced by the English decisions ${ }^{93}$ although they are not bound to do so. ${ }^{94}$ This is simply because of the strong influence the BEA had on the SABEA. ${ }^{95}$ According to Cowen the influence of English law has been more marked in negotiable instruments than any other branch of South African law. ${ }^{96}$

${ }^{84}$ See par 4 above.

85 This was clear and did not have to be addressed.

${ }^{86}$ See par 6 above.

87 This is the same idea that was expressed by academic writers (see Tobias 2009 Banking \& Finance LR 347); McLoughlin Introduction to Negotiable Instruments 129; and Oelofse 1981 Modern Business Law 53).

88 Same as s 13(2) of the BEA.

89 See par 6 above.

90 Tobias 2009 Banking \& Finance LR 347.

91 See par 6 above.

92 Guest Chalmers and Guest on Bills of Exchange, Cheques and Promissory Notes confirmed the decision in Royal Bank of Scotland $v$ Tottenham [1894] supra 59 (see par 9 above).

93 Malan et al Malan on Bills of Exchange, Cheques and Promissory Notes in South African Law 30.

94 Holmes JA concluded that "it is safely appropriate to follow English judicial decisions and text-books on the subject, as well as the writers in this country" (see Standard Bank of SA Ltd $v$ Sham Magazine Centre supra par 502F-G). See also Bank of Baroda Limited v Punjab National Bank Limited [1944] AC 176 (PC) 183 for the influence exerted by the BEA.

95 The Roman-Dutch law had a very slight influence (see Malan et al Malan on Bills of Exchange, Cheques and Promissory Notes in South African Law 30).

96 Cowen The Law of Negotiable Instruments in South Africa 146. 
In closure, a cheque is payable on demand even though it is post-dated. The effect is that the demand cannot be made lawfully until the date indicated. ${ }^{97}$ When someone draws a post-dated cheque, he gives a mandate to his bank not to effect payment before the arrival of the post-date. ${ }^{98}$ The bank will thus not make payment of a post-dated cheque before the date indicated. If the bank makes payment adversely before the post-date, it will not be entitled to debit its customer's account. The bank may debit its customer's account only lawfully when the post-date arrives.

McLoughlin Introduction to Negotiable Instruments 129. See also par 6 above.

98 See par 6 above. 